University of Nebraska - Lincoln

DigitalCommons@University of Nebraska - Lincoln

\title{
Vertical Profile and Temporal Variation of Chlorophyll in Maize Canopy: Quantitative “Crop Vigor” Indicator by Means of Reflectance-Based Techniques
}

\author{
Verónica Ciganda \\ INIA La Estanzuela \\ Anatoly A. Gitelson \\ University of Nebraska - Lincoln, agitelson2@unl.edu \\ James S. Schepers \\ United States Department of Agriculture, Agricultural Research Service, james.schepers@gmail.com
}

Follow this and additional works at: https://digitalcommons.unl.edu/natrespapers

Part of the Natural Resources and Conservation Commons

Ciganda, Verónica; Gitelson, Anatoly A.; and Schepers, James S., "Vertical Profile and Temporal Variation of Chlorophyll in Maize Canopy: Quantitative "Crop Vigor" Indicator by Means of Reflectance-Based Techniques" (2008). Papers in Natural Resources. 256.

https://digitalcommons.unl.edu/natrespapers/256

This Article is brought to you for free and open access by the Natural Resources, School of at DigitalCommons@University of Nebraska - Lincoln. It has been accepted for inclusion in Papers in Natural Resources by an authorized administrator of DigitalCommons@University of Nebraska - Lincoln. 


\title{
Vertical Profile and Temporal Variation of Chlorophyll in Maize Canopy: Quantitative "Crop Vigor" Indicator by Means of Reflectance-Based Techniques
}

\author{
Verónica Ciganda, Anatoly Gitelson,* and James Schepers
}

\begin{abstract}
Chlorophyll (Chl) content is among the most important crop biophysical characteristics. Chlorophyll can be related to photosynthetic capacity, thus, productivity, developmental stage, and canopy stresses. The objective of this study was to quantify and characterize the temporal variation of Chl content in the vertical profile of maize (Zea mays L.) canopies by means of a reflectance-based, nondestructive methodology. A recently developed technique that relates leaf reflectance with leaf pigment content has been used for accurate leaf Chl estimation. The technique employs reflectance in two spectral bands: in the red edge $(720-730 \mathrm{~nm})$ and in the near infrared $(770-800 \mathrm{~nm})$. More than 2000 maize leaves were measured for reflectance and total and green area during a growing season. A bell-shaped curve showed a very good fit for the vertical distribution of Chl content regardless of crop growth stage. The parameters and coefficients of the bell-shape function were found to be very useful to interpret temporal changes in the vertical profile of each variable. Comparisons among Chl, leaf area index (LAI) and green LAI showed that $\mathrm{Chl}$ content was more sensitive to changes in the physiological status of maize than other biophysical characteristics. The quantification of $\mathrm{Chl}$ content in canopy should be seen as a useful tool to complement the information on green LAI or LAI. Its applicability will help to improve the understanding of the crop ecophysiology, productivity, the radiation use efficiency and the interplant competition.
\end{abstract}

$\mathrm{P}$ HYSIOLOGICAL STATUS of a crop is commonly characterized through the LAI, defined as the total leaf area per unit area of ground beneath them (Watson, 1947), or the green LAI, defined as the green area of leaves per unit area of ground beneath them. These biophysical characteristics have been considered basic to growth analysis and important in current estimates of crop canopies' potential photosynthesis (e.g., Francis et al., 1969).

Specifically for the case of maize, leaf area and the vertical leaf area profile influence the interception and utilization of solar radiation and, consequently, drive dry matter accumulation and grain yield (Valentinuz and Tollenaar, 2006). Also, the vertical distribution of leaf area wtihin maize canopies, described using Gaussian (Boedhram et al., 2001; Yang and Alley, 2005) and bell-shape models(Dwyer et al., 1992; Keating and Wafula, 1992; Valentinuz and Tollenaar, 2006), has been suggested as an important characteristic for estimating radiation interception in canopy photosynthesis modeling. However, both LAI and green LAI have some important restrictions in characterizing crop physiological status or vigor. In the case of LAI, it is not possible to differentiate among

V. Ciganda, INIA La Estanzuela, CC 39173 Colonia, Uruguay; A. Gitelson, Center for Advanced Land Management Information Technology, School of Natural Resources, and J. Schepers, USDA-ARS and Dep. of Agronomy and Horticulture, Univ. of Nebraska-Lincoln, NE 68583-0973. Received 25 Sept. 2007. ${ }^{*}$ Corresponding author (agitelson2@unl.edu).

Published in Agron. J. 100:1409-1417 (2008). doi:10.2134/agronj2007.0322

Copyright $(2008$ by the American Society of Agronomy, 677 South Segoe Road, Madison, WI 53711. All rights reserved. No part of this periodical may be reproduced or transmitted in any form or by any means, electronic or mechanical, including photocopying, recording, or any information storage and retrieval system, without permission in writing from the publisher. actual status of the leaves since either alive or green leaves are considered the same as dead or necrotic leaves. As a result, LAI can greatly overestimates the photosynthetic functional components, especially in reproductive and senescence phenological stages. Green LAI, distinguishing green from nongreen leaf tissue, is a more accurate expression of the actual photosynthetic functional components. However, since there is no quantitative threshold to use in this determination, green LAI is subjective.

The importance of studying Chl content in vegetation has been recognized for decades (e.g., Danks et al., 1984). Long- or medium-term changes in Chl can be related to photosynthetic capacity (thus, productivity), developmental stage, and canopy stresses (e.g., Ustin et al., 1998). It was suggested that Chl could be the community property most directly relevant to the prediction of productivity (e.g., Lieth and Whittaker, 1975; Dawson et al., 2003). Foyer et al. (1982) further affirmed that “...all quantitative means for expressing photosynthetic rate in current use (for example, ground area, fresh weight) carry inescapable disadvantages. Chlorophyll is likely to remain the universal basis for expressing photosynthetic rate..." The energy absorbed by the canopy can only be transferred to the dark reaction of photosynthesis by Chl. Therefore, Chl content constitutes a surrogate for the amount of energy that can be transferred to the dark reaction of photosynthesis. Following this logic, it was shown that the $\mathrm{Chl}$ accounted for more than $98 \%$ of gross primary production variation in both maize and soybean (Gitelson et al., 2006a, 2008).

The $\mathrm{Chl}$ in leaves is responsible for the variability in greenness within a canopy; it reflects a wide range of photosynthetic activity from very dark green photosynthetically active leaves to pale green or almost senescent leaves. At the same time, the dis-

Abbreviations: Chl, chlorophyll; LAI, leaf area index; $\mathrm{CI}_{\text {red edge }}$, Red Edge Chlorophyll Index; PAR, absorbed photosynthetically active radiation. 
tribution of $\mathrm{Chl}$ among leaves ultimately depends on the canopy acclimation to light penetration (Kull, 2002). For example, acclimation to low irradiance reduces the electron transport capacity per unit of Chl, while it increases the proportion of Chl (Kull, 2002). This could be the case with lower leaves in a maize canopy during active photosynthetic periods, before senescence. In addition, phenology plays an important role in the variability of $\mathrm{Chl}$ among leaves. At the same stage, the $\mathrm{Chl}$ content of a recently emerged leaf is different from those that have already expanded or those that are senescing.

In maize plants, the position and orientation of leaves seem to be more important in determining photosynthetic capacity of leaves than their chronological appearance. This concept is supported by several studies that have reported a top to bottom profile of leaf senescence in maize hybrids (e.g., Wolfe et al., 1988; Borras et al., 2003; Valentinuz and Tollenaar, 2004). These studies describe a profile of maize leaf senescence progressing from the bottom leaves upward, as well as from the top leaves downward, resulting in leaves positioned around the ear remaining green the longest. These leaves are not the youngest but the ones with the highest photosynthetic capacity: the longer a leaf lives and remains active, the greater the net capture of $\mathrm{CO}_{2}$ (Long, 1991).

Temporal changes in the vertical profile of canopy $\mathrm{Chl}$ are driven by the distribution of $\mathrm{Chl}$ within leaves: the $\mathrm{Chl}$ in an individual leaf varies during the stages of its life cycle: expansion, longevity, and senescence (Lizaso et al., 2003). At a specific growth stage, the distribution of $\mathrm{Chl}$ within maize leaves is, in general, quite homogeneous. However, either biotic or abiotic factors could induce stress in a plant affecting specific processes on individual leaves resulting both in a loss of $\mathrm{Chl}$ and in a change in its distribution pattern (Barton, 2000).

The Chl content of a canopy integrates the green leaf area and the intensity of greenness, that is, total canopy $\mathrm{Chl}$ is a quantitative measure of the size and the functionality of the photosynthetic components. Even though the relationship between leaf $\mathrm{Chl}$ and actual photosynthetic canopy area is well recognized, very little information is available about the vertical distribution of $\mathrm{Chl}$ and how it changes during the growing season.

While both destructive and nondestructive techniques have been used to estimate LAI and green LAI (e.g., leaf area meters, Montgomery's formula, plant canopy analyzer using transmittance measurement, Montgomery, 1911; remote LAI estimation, Gitelson et al., 2003a), up to now the Chl content in a canopy has not been used as a feasible crop biophysical characteristic or as an accurate measure of crop "vigor" due to the lack of practical, fast, and nondestructive methodologies to quantify Chl. Recently, a semi-analytical model that relates reflectance and $\mathrm{Chl}$ content in leaves was developed (Gitelson et al., 2003a, 2006b). Using this model for estimation of Chl in leaves, Ciganda et al. (2008) developed a fast technique for estimating $\mathrm{Chl}$ in maize canopies under field conditions. The technique is based on nondestructive measurements of reflectance and the area of the collar or ear leaf. The objective of this study is to quantify and characterize the temporal variation of Chl content in the vertical profile of maize canopies across a range of agronomic growing conditions using a reflectance based, nondestructive technique.

\section{MATERIALS AND METHODS}

\section{Experimental Setups}

This study took advantage of an established research facility, which is part of the Carbon Sequestration Program at the University of Nebraska-Lincoln. The research facility consists of three agricultural fields of approximately 65 ha each. The cropping system was established in 2001 and differs among the three fields: field no. 1 is under continuous irrigated maize; field no. 2 is an irrigated maize-soybean [Glycine $\max ($ L.) Merr.] rotation; and field no. 3 is a rainfed maize-soybean rotation. The study took place in the 2005 growing season. Field no. 1 and no. 2 were planted with maize hybrids Dekalb 6375 (D-6375) and Pioneer brand 33B51 (P-33B51), respectively, at 85,000 seeds ha ${ }^{-1}$ with a row spacing of $76 \mathrm{~cm}$. Field no. 3 was planted with maize hybrid Pioneer brand 31G68 (P-31G68) at 62,500 seeds $\mathrm{ha}^{-1}$ with a row spacing of $56 \mathrm{~cm}$.

\section{Plant Sampling and Labeling Procedures}

Throughout the 2005 growing season, three plants were sampled on 15 dates (from V3-R6) from hybrids D-6375 and P-31G68 and on 13 dates (from V6-R6) from hybrid $\mathrm{P}-33 \mathrm{~B} 51$. A total of 128 plants were sampled resulting in approximately 2000 leaves being measured. On each sampling date, plants considered representative of the growing stage of the entire field were selected randomly from an area close to where remote canopy reflectance measurements were taken. Once the plants were selected, the collar or ear leaf was identified. The collar leaf was defined as the uppermost leaf whose leaf collar is visible (Ritchie et al., 1993) while the ear leaf was defined as the leaf next to the maize ear. Positions of the other leaves on each plant were numerically labeled with respect to the collar or the ear leaf position during vegetative or reproductive stages, respectively. The collar or ear leaf was labeled as leaf no. 0 . The leaves above or below leaf no. 0 were identified with a "+" or a “-” sign, respectively, followed by the correspondent position number. For example, the first leaf above the ear/collar leaf was identified as +1 , the second one as +2 , the third one +3 , etc., up to the top leaf. On the contrary, the first leaf below the ear/collar leaf was identified as -1 , the second as -2 , the third one as -3 until the closest leaf to the ground was reached. After labeling, the leaves were cut from the stem, placed in a sealed plastic bag, and brought to the laboratory inside a cooler.

\section{Estimation of Leaf Chlorophyll Content, Total and Green Leaf Area Index}

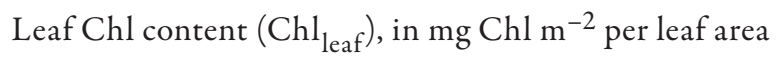
was estimated using a recently developed technique that relates leaf reflectance with leaf pigment content (Gitelson et al., 2003b, 2006b). Reflectance of each leaf was measured in the spectral range from 400 to $900 \mathrm{~nm}$ using a leaf clip, with a $2.3-\mathrm{mm}$ diam. bifurcated fiber-optic cable attached to both an Ocean Optics USB2000 spectroradiometer and to an Ocean Optics LS-1 tungsten halogen light source. The leaf clip allows individual leaves to be held with a $60^{\circ}$ angle relative to the bifurcated fiber-optic. A Spectralon reflectance standard (99\% reflectance) was scanned before each leaf measurement. The software CDAP (CALMIT, 
University of Nebraska-Lincoln Data Management

Program) was used to acquire and process the data from the sensor. The reflectance at each wavelength was calculated as the ratio of upwelling leaf radiance to the upwelling radiance of the standard.

One of the models, the so-called Red Edge Chlorophyll Index $\left(\mathrm{CI}_{\text {red edge }}\right)$, was suggested for $\mathrm{Chl}$ retrieval in both anthocyanin-containing and anthocyanin-free leaves (Gitelson et al., 2003b, 2006b). This model is based on reflectance in the red edge $\left(\mathrm{R}_{\text {red edge }}\right)$ and near infrared $\left(\mathrm{R}_{\mathrm{NIR}}\right)$ wavebands and defined as:

$$
\mathrm{CI}_{\text {red edge }}=\left(\mathrm{R}_{\mathrm{NIR}} / \mathrm{R}_{\text {red edge }}\right)-1
$$

where $R_{\text {NIR }}$ is reflectance in the near infrared range from 770 through $800 \mathrm{~nm}$ and $R_{\text {red edge }}$ is the reflectance in the red edge range from 720 to $730 \mathrm{~nm}$.

The relationship between analytically determined Chl and $\mathrm{CI}_{\text {red edge }}$ for maize has been established by Ciganda et al. (2008). This relationship was described by a linear best fit function with root mean square error (RMSE) of Chl estimation of $<51 \mathrm{mg} \mathrm{Chl} \mathrm{m}^{-2}$ in the Chl range from 100 to more than $800 \mathrm{mg} \mathrm{m}^{-2}$ and coefficient of determination of $r^{2}>0.94:$

$$
\mathrm{Chl}_{\text {leaf }}\left(\mathrm{mg} \mathrm{m}^{-2}\right)=37.904+1353.7 \times \mathrm{CI}_{\text {red edge }}
$$

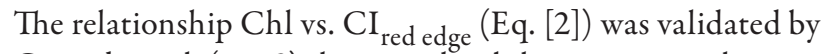
Ciganda et al. (2008) showing the ability to accurately estimate $\mathrm{Chl}$ and was used in this study to retrieve leaf $\mathrm{Chl}$ from leaf reflectance measured in two spectral bands.

Total amount of $\mathrm{Chl}$ in individual leaves ( $\mathrm{Chl}$ total $)$, in gram of $\mathrm{Chl}$ in total area of individual leaves, was calculated following a methodology developed by Ciganda et al. (2008). The area of each leaf, $S_{\text {leaf }}$, or the area of each leaf section (in the case of leaves with sections of different greenness), $S_{\text {section' }}$ was measured with a leaf area meter (Model LI-3100A, LI-COR, Inc., Lincoln, NE). Total amount of Chl in individual leaves was calculated as the product of leaf area, $S_{\text {leaf, }}$ (in $\mathrm{m}^{2}$ ) and its Chl content, $\mathrm{Chl}_{\text {leaf }}\left(\right.$ in $\mathrm{mg} \mathrm{Chl} \mathrm{m}^{-2}$ ) using the equation:

$$
\text { Chl }{ }_{\text {leaf }}^{\text {total }}=\mathrm{Chl}_{\text {leaf }} \times \mathrm{S}_{\text {leaf }}
$$

In the case of leaves with two or more sections of different greenness (i.e., " $\mathrm{m}$ " sections), total amount of Chl of the entire individual leaf was calculated as the sum of the products for each section using the following equation:

$$
\text { Chl }{ }_{\text {leaf }}^{\text {total }}=\sum_{i=1}^{m} \mathrm{Chl}_{i \text { section }} \times S_{i \text { section }}
$$

Total leaf area was calculated as the sum of areas of all the sections of a leaf. Thus, leaf sections with $\mathrm{Chl}$ values including sections with $\mathrm{Chl}=0 \mathrm{mg} \mathrm{m}^{-2}$ were included in the total leaf area. On the other hand, green leaf area was calculated as the sum of all the leaf sections with Chl values greater than zero. Finally, LAI and green LAI were calculated as a ratio of total leaf area and green leaf area, respectively, to ground area occupied by an individual plant.
Total amount of $\mathrm{Chl}$ in the canopy $\left(\mathrm{Chl}_{\text {canopy }}\right)$ expressed as the amount of $\mathrm{Chl}$ per unit of ground area (i.e., $\mathrm{g} \mathrm{Chl} \mathrm{m}^{-2}$ ), was calculated as the sum of the total amount of $\mathrm{Chl}$ of individual leaves of each plant divided by the ground area beneath one plant $\left(S_{g}\right)$ :

$$
\mathrm{Chl}_{\text {canopy }}=\sum_{i=1}^{n} \mathrm{Chl} \mathrm{lotal}_{\text {leaf }}^{\text {tal }} / \mathrm{S}_{\mathrm{g}}
$$

where $n$ is number of leaves in each plant.

\section{Vertical Distribution of Chlorophyll, Leaf Area Index, and Green Leaf Area Index in Canopy}

The vertical distribution of Chl, LAI, and green LAI in the canopy profile was described using a slightly skewed bell-shape model (Dwyer and Stewart, 1986; Keating and Wafula, 1992; Valentinz and Tollenaar, 2006) in the form

$$
Y_{n}=Y_{0} \times \exp \left[a \times\left(x_{n}-x_{\mathrm{o}}\right)^{2}+b \times\left(x_{n}-x_{\mathrm{o}}\right)^{3}\right]
$$

where $Y_{n}$ is the variable (i.e., Chl, LAI, or green LAI) for the $n$th leaf position; $x_{n}$ is the $n$th leaf position; $x_{\mathrm{o}}$ is the leaf position with a maximum value of $Y=Y_{0}$ (i.e., it is the inflection point of the bell-shaped curve); and $a$ and $b$ are empirical variables that control, respectively, the degree of breadth and skewness of the vertical distribution of the fitted variable. The coefficients $a, b$, and $x_{\mathrm{o}}$ of the bell-shaped function were estimated for each sampling date and hybrid using a nonlinear regression performed using PROC N-LIN SAS (SAS Institute, 2004).

\section{RESULTS AND DISCUSSION Seasonal Trend of the Vertical Distribution of Leaf Area Index, Green Leaf Area Index, and Chlorophyll}

The diverse cropping systems among the three fields plus the intrinsic differences among hybrid physiologies were reflected in different values of LAI but not in the shape of its vertical distribution (Fig. 1). A bell shape and symmetric vertical distribution of LAI was consistently observed across hybrids and throughout most of the growing season with a maximum around leaf no. 0 and minimum for top and bottom leaves. During the vegetative period and until tasseling (VT), increase in LAI was observed due to both the emergence of new leaves and the expansion of the already emerged leaves. Most of the senescent leaves remained on the plants through the end of the growing season. Thus, LAI was not greatly affected by leaf aging or the senescence processes.

The differences in the shape of the vertical distribution of green LAI among hybrids were minimal (Fig. 2). The vertical profile of this characteristic showed a slight skew after tasseling. The skewness became stronger after physiological maturity due to the intensification of the senescence process of the bottom leaves. Maximum values of green LAI were observed around leaf no. 0 , that is, collar or ear leaf during vegetative or reproductive periods, respectively. From V6 to tasseling, LAI increased about 2.6-fold. Maximum values remained relatively high up to stage $\mathrm{R} 4$. The maximum magnitude decreased by 2.5-fold through the end of the growing season. Green LAI was minimal in both top and bottom leaves. Top 
Ciganda, Gitelson \& Scepers in Agronomy Journal (2008) 100: 1,409-1,417.

Copyright 2008, American Society of Agronomy. Used by permission.
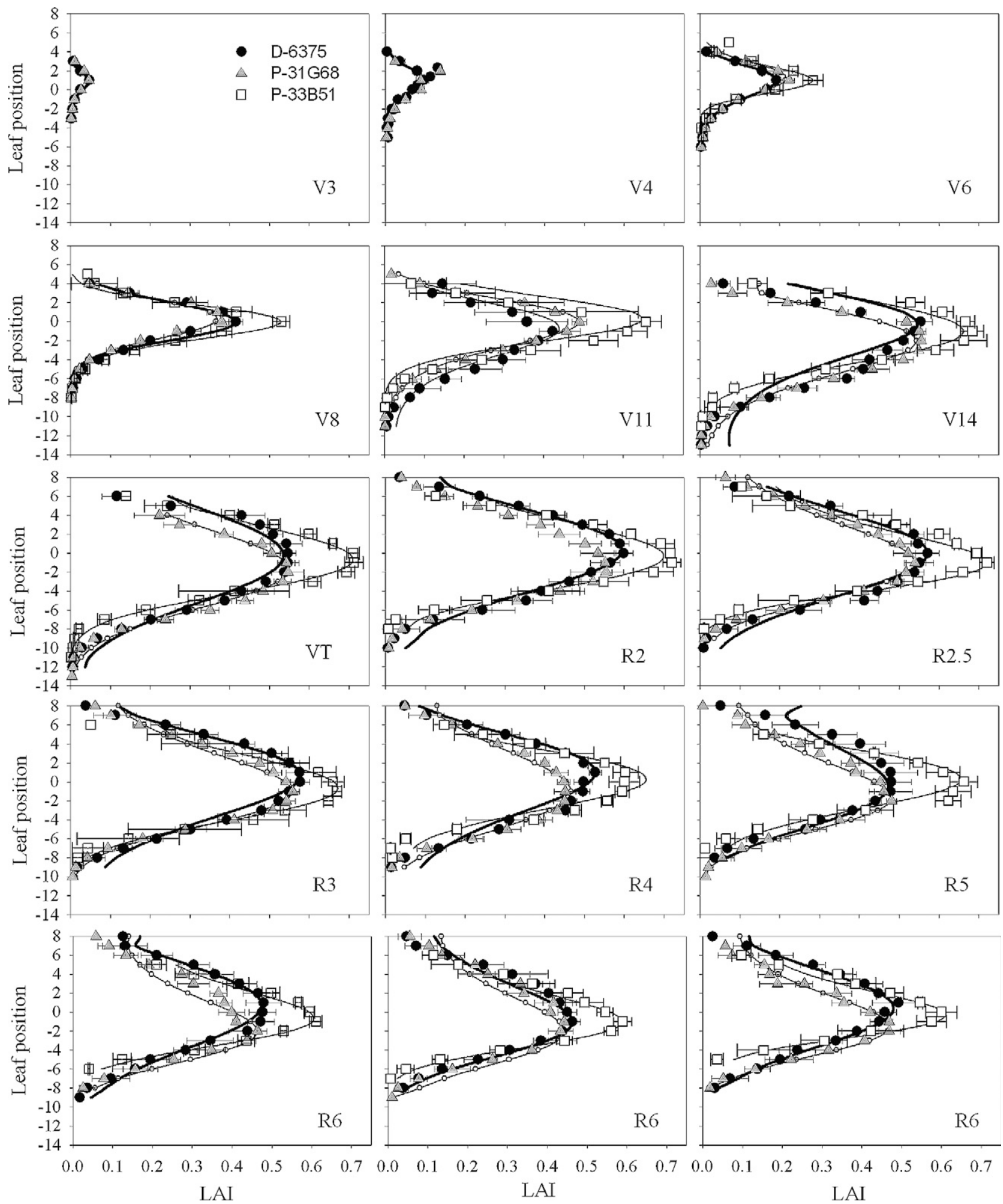

Fig. I. Vertical distribution of leaf area index (LAI) in canopy at 15 selected growth stages (V3-R6) of three maize hybrids D-6375, P-3 IG68, and P-33B5I. The y axis represents leaf position: the collar or ear leaf was labeled as leaf no. 0 . The leaves above or below leaf no. 0 were identified with a "+" or a "_" sign, respectively, followed by the corresponding position number. For example, the first leaf above the ear/collar leaf was identified as +1 , the second one as +2 , the third one +3 , etc., up to the top leaf. On the contrary, the first leaf below the ear/collar leaf was identified as $-I$, the second as -2 , the third one as -3 until the closest leaf to the ground was reached. Horizontal bars represent the standard deviation of the average of LAI three plants. Solid lines represent the fit of the bell-shape function for each hybrid and growing stage.

leaves are the youngest and with smaller areas than leaves farther down in the canopy. In contrast, bottom leaves are the oldest but they do not expand as much as center leaves (around leaf no. 0) and they lose green tissue due to senescence beginning relatively early in the growing season.
The shape of vertical profile and values of LAI and green LAI were similar during vegetative period up to tasseling (Fig. 1 and 2). After this stage, however, the distribution of green LAI skewed toward the higher leaves on initiation of senescence in lower leaves (Fig. 2). Vertical distribution of chlorophyll was also a bell shape 
Ciganda, Gitelson \& Scepers in Agronomy Journal (2008) 100: 1,409-1,417.

Copyright 2008, American Society of Agronomy. Used by permission.
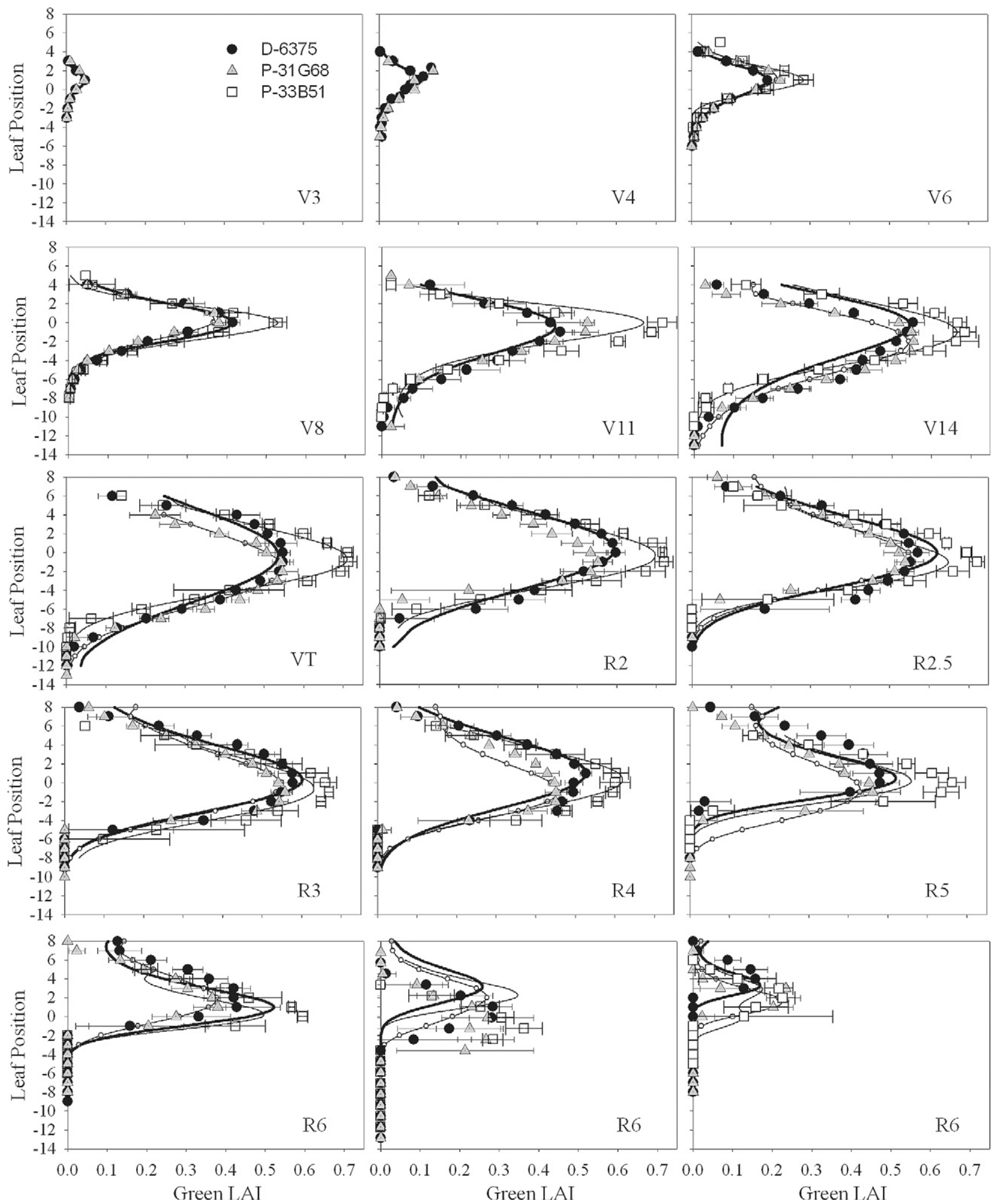

Fig. 2. Vertical distribution of green leaf area index (LAI) in canopy at 15 selected growth stages (V3-R6) of three maize hybrids D-6375, P-3 IG68, and P-33B5I. The y axis represents leaf position as in Fig. I. Horizontal bars represent the standard deviation of the average of green LAI of three plants. Solid lines represent the fit of the bell-shape function for each hybrid and growing stage.

(Fig. 3). The distribution skewed toward the top leaves from tasseling until the end of the growing season. The senescence process (i.e., the loss of $\mathrm{Chl}$ ) strongly affected the variability in Chl vertical distribution. Similar to LAI and green LAI, maximal Chl content was observed around leaf no. 0 (i.e., collar or ear leaf during vegetative or reproductive periods, respectively). From V6 until tasseling, maximal values of Chl content increased up to four-fold. The $\mathrm{Chl}$ remained relatively high up to $\mathrm{R} 4$ and then decreased during late reproductive stages.

The Chl content was minimal in both top and bottom leaves. As a result of the adaptation of the top leaves to high incoming irradiance, these leaves are usually low in Chl content (Kull, 2002). 
Ciganda, Gitelson \& Scepers in Agronomy Journal (2008) 100: 1,409-1,417.

Copyright 2008, American Society of Agronomy. Used by permission.
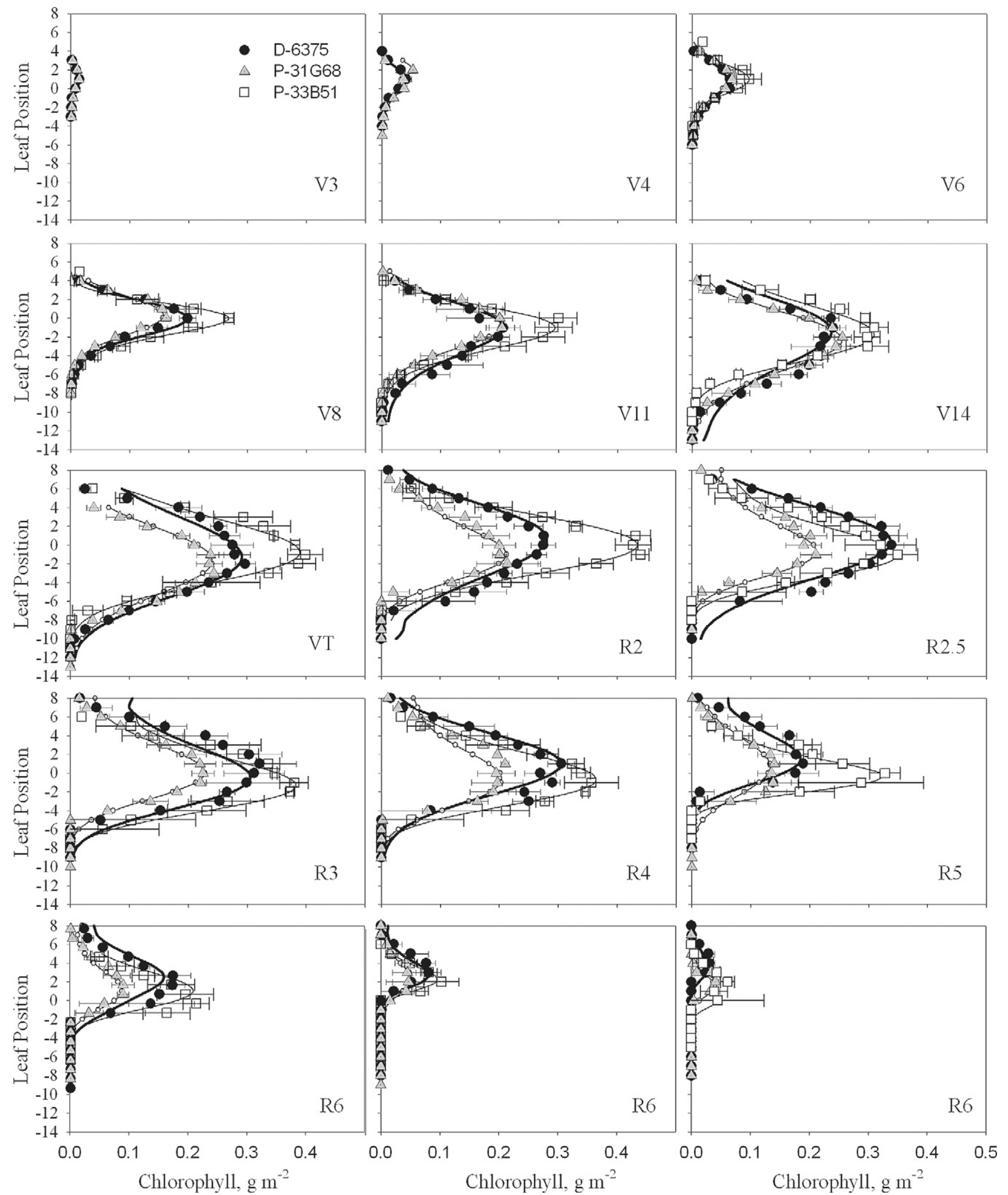

Fig. 3. Vertical distribution of chlorophyll in canopy per ground area at I5 selected growth stages (V3-R6) for three maize hybrids: D-6375, P-3 IG68, and P-33B5I. The y axis represents leaf position as in Fig. I. Horizontal bars represent the standard deviation of the average of canopy $\mathrm{Chl}$ of three plants.

Also, these leaves are the youngest and have smaller areas than lower leaves. In contrast, bottom leaves are the oldest and a loss of Chl occurred relatively early in the season. Top leaves clearly begin to senesce after physiological maturity (R5), while leaf no. 0 and the ones immediately above remained green much longer.
After tasseling, Chl distribution began to skew due to the decrease in Chl of leaves positioned near the bottom of the canopy. The skewness markedly increased and the total amount of $\mathrm{Chl}$ in all leaves decreased after physiological maturity (R4). 


\section{Seasonal Pattern of the Fitted Bell- Shape Curve Parameters}

In general, the bell-shaped curve showed a very good fit with the vertical distributions of LAI and green LAI. Total canopy Chl, expressed in $\mathrm{g} \mathrm{Chl} \mathrm{m}^{-2}$, was also very well described by this function. The parameter $\mathrm{Y}_{0}$, that is, the maximum value of the fitted parameter, showed a similar temporal behavior for LAI, green LAI, and Chl from early vegetative growth up to tasseling (Fig. 4a, 4d, and 4g).

The LAI reached maximum values after tasseling and remained virtually invariable until the end of the growing season and insensitive to any change in plant greenness or Chl content (Fig. 4a). In contrast, during reproductive and senescence stages the maximum value for green LAI and Chl decreased significantly reaching values near zero at the end of the growing season. Such decline is mainly attributed to the loss of photosynthetic tissue and, thus, Chl.

The magnitude of the parameter $Y_{0}$ varied among hybrids. This variation can be attributed both to hybrid characteristics and growing conditions (Fig. 4a, 4d, and 4g). Remarkably, the magnitudes of the variation between hybrids were very different for biophysical characteristics measured. At stages of maximum greenness (from tasseling through $\mathrm{R} 3$ ), the difference in $Y_{0}$ between hybrids P-31G68 and D-6375 for LAI and green LAI was $<7 \%$

(Fig. 4d), while for $\mathrm{Chl}$ it exceeded $30 \%$ and reached $37 \%$ at later reproductive stages. These results showed that $\mathrm{Chl}$ was more sensitive to the physiological status of maize than LAI or green LAI.

Coefficient $a$ describes the breath of the curve and its value shows how sharp the curve rises or falls: low values of $a$ indicate that the biophysical variable rises sharply or falls sharply (Keating and Wafula, 1992). During the vegetative stages, all three biophysical characteristics (LAI, green LAI, and Chl) showed an increase in the breath of the curve (i.e., an increase in a) with very similar values (Fig. 4b, 4e, and 4h). At stages of maximum greenness, the breath of the curve remained almost constant for the three variables indicating their almost invariable temporal behavior at this stage. During the reproductive stage, however, the value of coefficient $a$ remained constant for LAI while it noticeably declined for green LAI and Chl. In the case of LAI, most of the senescent leaves remained on the plants through the end of the growing season. Thus, LAI was not greatly affected by leaf aging or senescence processes. In contrast, the decline in coefficient $a$ for green LAI and $\mathrm{Chl}$ is caused by the senescence of the lower leaves followed by the senescence of the top leaves (Wolfe et al., 1988; Borras et al.,
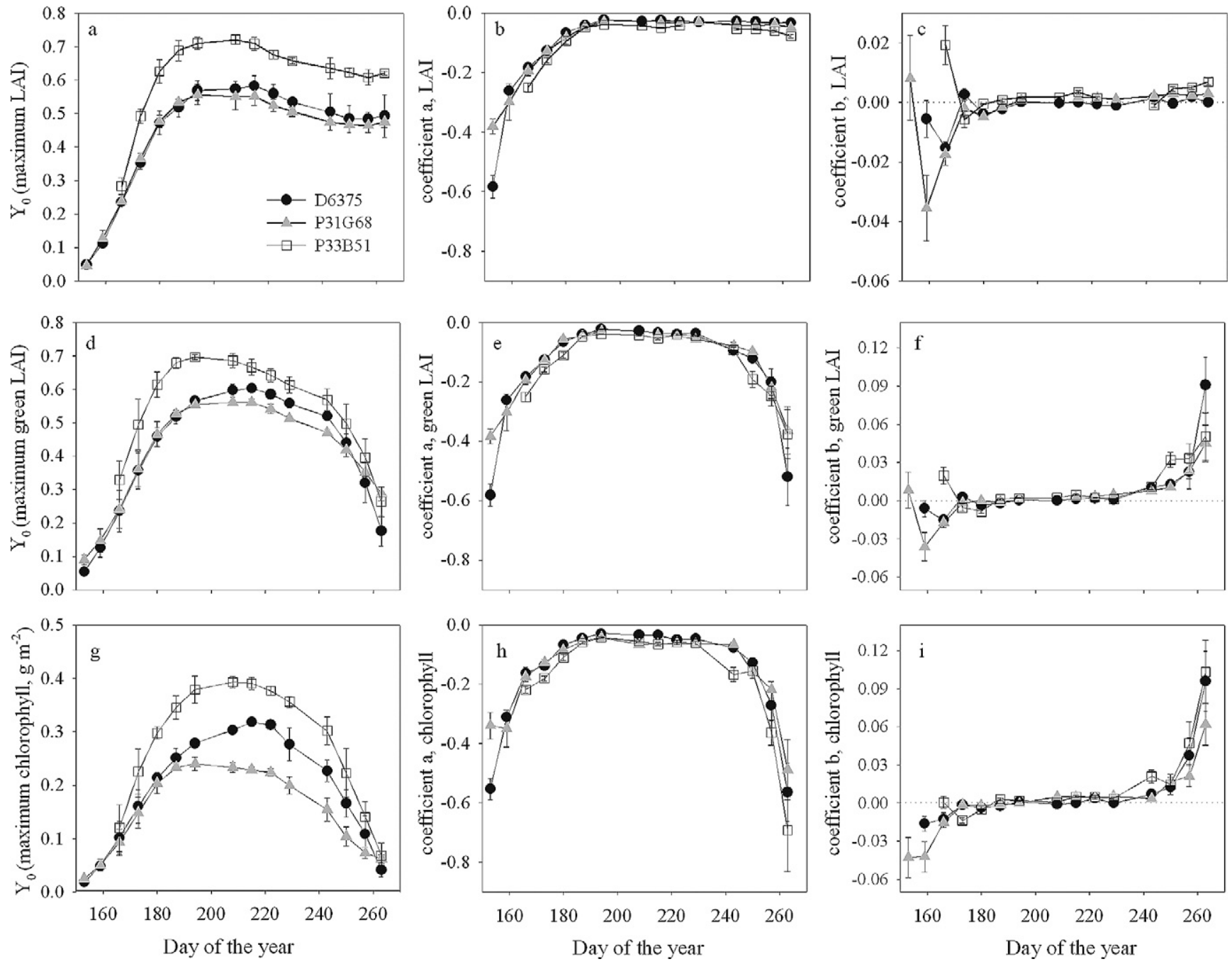

Fig. 4. Temporal progress of the parameter $Y_{0}, a$, and $b$ of the bell-shape function (Eq. [4]) fitted for the vertical distribution of leaf area index (LAI), green LAl, and total canopy chlorophyll (ChI) content for hybrids D-6375 (filled circle), P-33B5I (rectangle), and P-3IG68 (triangle) during the growing season. $Y_{0}$ indicates the maximum value of the fitted variable (LAI, green LAI, and $\mathrm{Chl}$ ), $a$ is the breath of the curve, and $b$ indicates the position of $Y_{0}$ with respect to 0 -leaf. 

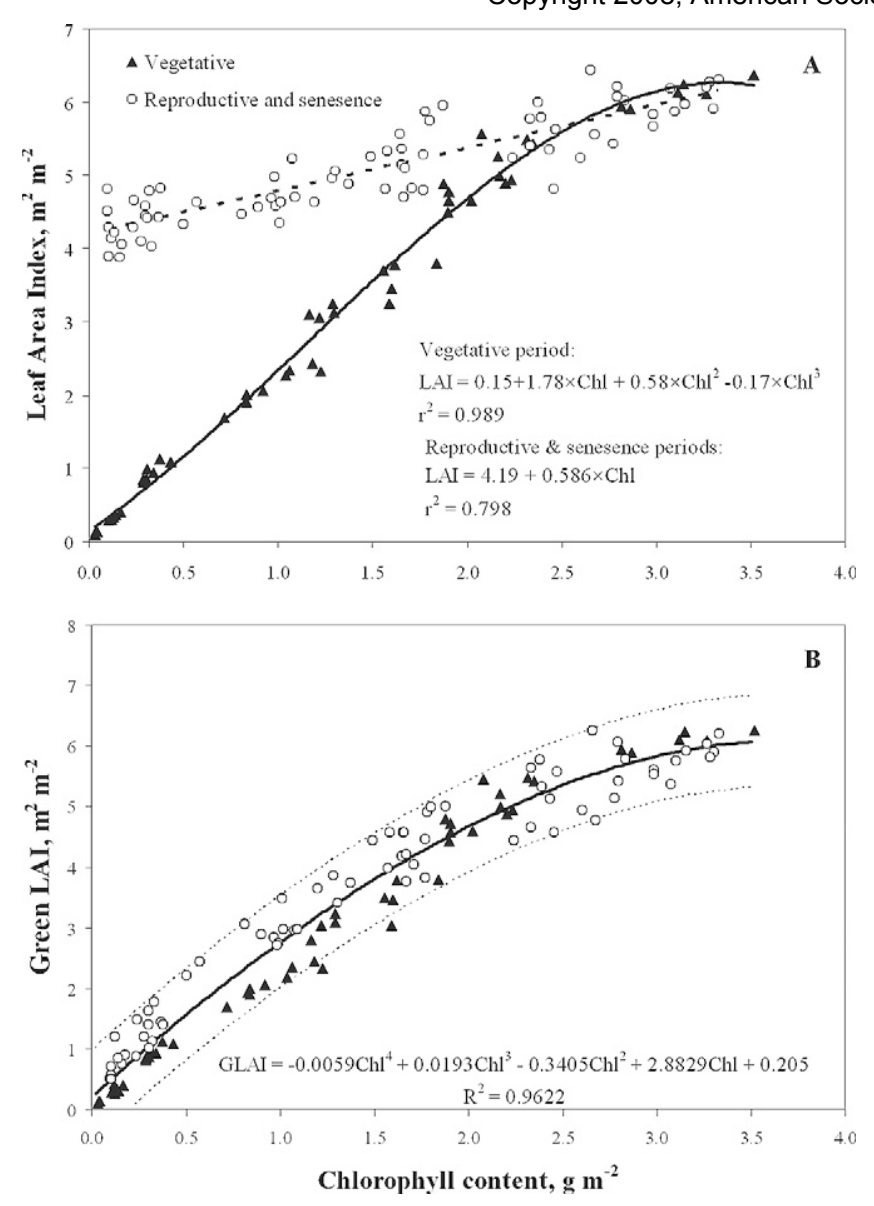

Fig. 5. Relationship between leaf area index (LAI) (A) and green LAl (B) vs. total canopy chlorophyll (Chl) content ( $\mathrm{g} \mathrm{Chl}$ $\mathrm{m}^{-2}$ ground area). (A) Data for the vegetation period was fitted with a quadratic function, while a linear function was the best fit for reproductive and senescence periods. (B) Best fit function (solid line) and two root mean square error (dashed lines) are shown.

2003; Valentinuz and Tollenaar, 2004). These senescence patterns constrained the width of the bell-shaped curve from both extremes of the canopy: bottom and top. Interestingly, for all three biophysical variables, the value of coefficient $a$ was very close among the three hybrids. Thus, while there were some differences in the magnitude of $Y_{0}$ among hybrids for each variable, the shape of the vertical distribution (coefficient $a$ ) was similar for the three hybrids.

Coefficient $b$ is the indicator of the skewness of the bell-shape fitted curve. Negative values of $b$ are associated with biophysical variables that are skewed toward the bottom leaves (i.e., toward leaves positioned below leaf no. 0 ). Positive values of $b$ result in profiles that are skewed toward the top leaves (i.e., $x_{n}>x_{0}$ ). A value of zero means that the vertical profile of the variable is symmetrical around $x_{0}$ (Keating and Wafula, 1992). The $b$ value showed some variability at early vegetative stages for the three biophysical variables. Later in the growing season and almost up to the end, coefficient $b$ for

Table I. Intercept $\left(b_{0}\right)$, linear term $\left(b_{1}\right)$, quadratic term $\left(b_{2}\right)$, and coefficient of determination $\left(r^{2}\right)$ of second order polynomial relationship (Green LAI $=b_{0}+b_{1} \times C h l+b_{2} \times C^{2} l^{2}$ ) between green leaf area index and total canopy chlorophyll content for two growth periods: the vegetative growth period (V3-VT) and the reproductive and senescence period (R2-R6).

\begin{tabular}{lcclcl}
\hline \multicolumn{1}{c}{ Growing period } & $\boldsymbol{n}$ & $\mathbf{r}^{\mathbf{2}}$ & \multicolumn{1}{c}{$\mathbf{b}_{\mathbf{0}}$} & \multicolumn{1}{c}{$\mathbf{b}_{\mathbf{1}}$} & \multicolumn{1}{c}{$\mathbf{b}_{\mathbf{2}}$} \\
\hline Vegetative (V3 through VT) & 57 & 0.984 & -0.0303 & 2.7462 & -0.2395 \\
Reproductive and senescence (R2 through R6) & 71 & 0.964 & 0.467 & 2.985 & -0.413 \\
\hline
\end{tabular}

LAI was equal to zero indicating symmetry around leaf no. 0 (Fig. $4 \mathrm{c}, 4 \mathrm{f}$, and $4 \mathrm{i})$. The vertical profiles of green LAI and Chl during the vegetative and early reproductive periods were also symmetrical around leaf no. 0 (i.e., coefficient $b$ is equal to zero). However, at late reproductive stages, the profiles clearly skewed toward the upper leaves. Such skewness is due to the progress of senescence from the bottom leaves. Only few leaves above the ear leaf remained green a little bit longer with low values of $\mathrm{Chl}$ content.

\section{Leaf Area Index and Green Leaf Area Index vs. Chlorophyll}

The relationship between LAI and total canopy Chl per ground area showed hysteresis; these biophysical characteristics were related in a very different way during the vegetative stage and the reproductive and senescence stages (Fig. 5A). Interestingly, the same behavior has been found for relationships between $\mathrm{Chl}$ and fraction of absorbed photosynthetically active radiation (PAR) as well as between Chl and PAR absorbed by photosynthetically active ("green") vegetation (Viña and Gitelson, 2005). Note that during the vegetative period the increase in LAI was followed by a corresponding increase in Chl. Specifically, during this period Chl and LAI were positively associated; Chl and LAI increased almost synchronically up to LAI values that reached $5.0 \mathrm{~m}^{-2} \mathrm{~m}^{-2}$, and Chl values of $\sim 2.5 \mathrm{~g} \mathrm{~m}^{-2}$ (Fig. $5 \mathrm{~A}$ ). After this point, Chl continued to increase while LAI did not increase significantly and the slope of the relation LAI vs. Chl decreased notably. During reproductive stages and senescence, however, a drastic reduction of Chl occurred while LAI only slightly reduced (from $\sim 5.5$ to $4.5 \mathrm{~m}^{-2} \mathrm{~m}^{-2}$ ) (Fig. 5A). Thus, LAI remained almost invariable while a significant decline in Chl occurred during reproductive stages and until the end of the senescence period.

The relationship between green LAI and total canopy Chl content per ground area was essentially nonlinear and the best fit was found to be a fourth order polynomial (Fig. 5B) whereas for each of the growing periods, a quadratic model was found to be best (Table 1). The coefficients of determination between the two variables were 0.984 and 0.964 for the vegetative and reproductive periods (including senescence), respectively. The relationship still was hysteretic while it was much less pronounced than for the LAI vs. Chl relationship. For the same value of green LAI, the canopy Chl content was significantly smaller during the reproductive period than the vegetative period. Thus, the loss of Chl content that began during the reproductive period was not detected by measurements of green LAI.

Residuals of the relationship canopy Chl vs. green LAI were positive during the vegetative stages when LAI $<4 \mathrm{~m}^{2} \mathrm{~m}^{-2}$, while during the senescence stage they are negative. For the same green LAI values, the difference in $\mathrm{Chl}$ reached 80 to $90 \%$. Even at the end of the vegetative stage and during the reproductive stage when green LAI exceeded $4 \mathrm{~m}^{2} \mathrm{~m}^{-2}$ and $\mathrm{Chl}>1.5 \mathrm{~g} \mathrm{~m}^{-2}$, the difference reached $50 \%$. Thus, for the same green LAI the difference in Chl content exceeded $1.0 \mathrm{~g} \mathrm{~m}^{-2}$ for $\mathrm{Chl}$ ranging from 0 to $3.5 \mathrm{~g} \mathrm{~m}^{-2}$.

It is important to note that the canopy $\mathrm{Chl}$ vs. green LAI relationship was characterized by a pronounced decrease in slope for moderate-to-high Chl values. Thus, Chl continued to significantly increase (from 2 to more than $3.5 \mathrm{~g} \mathrm{Chl} \mathrm{m}^{-2}$ ) as green LAI reached its maximal values and became virtually insensitive to the crop physiological status ("greenness"). 


\section{Ciganda, Gitelson \& Scepers in Agronomy Journal (2008) 100: 1,409-1,417. \\ Copyright 2008, American Society of Agronomy. Used by permission.}

\section{CONCLUSIONS}

Using a fast and nondestructive reflectance-based technique it was possible to quantify and characterize the temporal variation in the vertical profile of maize $\mathrm{Chl}$ content. Vertical distributions of LAI, green LAI, and Chl were characterized by a bell- shaped function regardless of hybrid or crop growth stage. While similar bell-shaped distributions for green LAI have also been reported by Dwyer and Stewart (1986), Keating and Wafula (1992) and Valentinuz and Tollenaar (2006), to the best of our knowledge, this is the first report on vertical distribution of Chl in a maize canopy. The parameters and coefficients of bell-shape functions were found to be very useful to interpret temporal changes in the vertical profile of each variable.

Bell-shaped function coefficients $a$ and $b$ for green LAI and Chl described very well the bottom to top senescence pattern of maize and the shift of its maximum values toward the upper leaves at very late reproductive stages. The relationships between total leaf area and green leaf area vs. leaf Chl content at tasseling and beyond changed from linear to quadratic. This change highlighted the greater sensitivity of $\mathrm{Chl}$ content to quantitatively describe the performance of green stands.

Relationships "LAI vs. Chl" and "green LAI vs. Chl" showed that the photosynthetic capacity of a canopy could differ for an equal or similar amount of leaf area measured in the canopy. It became clear that LAI greatly overestimated the photosynthetic capacity of the canopy after tasseling because it contains living, senescent, and necrotic leaf area. Green LAI quantifies the amount of green area but there is no distinction among the functionality of that green area. Differences in the photosynthetic capacity of green vegetation are mainly related to the amount of $\mathrm{Chl}$ pigments present in those tissues. Thus, those differences were possible to retrieve by quantifying the amount of Chl present in the canopy.

The quantification of Chl content should be seen as a useful tool to complement the information on green LAI or LAI. Its applicability will help to improve the understanding of the ecophysiology of a canopy, the radiation use efficiency, the interplant competition, and its productivity.

\section{ACKNOWLEDGMENTS}

We gratefully acknowledge the use of facilities and equipment provided by Center for Advanced Land Management Information Technologies (CALMIT), University of Nebraska-Lincoln. This research was supported partially by the U.S. Department of Energy: (a) EPSCoR program, Grant No. DE-FG-02-00ER45827 and (b) Office of Science (BER), Grant No. DE-FG03-00ER62996. A contribution of the University of Nebraska Agricultural Research Division, Lincoln, NE. This research was also supported in part by funds provided through the Hatch Act.

\section{REFERENCES}

Barton, C.V.M. 2000. A theoretical analysis of the influence of heterogeneity in chlorophyll distribution on leaf reflectance. Tree Physiol. 21:789-795.

Boedhram, N., T.J. Arkebauer, and W.D. Batchelor. 2001. Season-long characterization of vertical distribution of leaf area in corn. Agron. J. 93:1235-1242.

Borras, L., G.A. Maddoni, and M.E. Otegui. 2003. Leaf senescence in maize hybrids: Plant population, row spacing and kernel set effects. Field Crops Res. 82:13-26.

Ciganda, V., A. Gitelson, and J. Schepers. 2008. Non-destructive determination of maize leaf and canopy chlorophyll content. J. Plant Physiol. doi:10.1016/j.jplph.2008.03.004.

Danks, S.M., E.H. Evans, and P.A. Whittaker. 1984. Photosynthetic systems: Structure, function and assembly. John Wiley \& Sons, New York.
Dawson, T.P., P.R.J. North, S.E. Plummer, and P.J. Curran. 2003. Forest ecosystem chlorophyll content: Implications for remotely sensed estimates of net primary productivity. Int. J. Remote Sens. 24:611-617.

Dwyer, L.M., and D.W. Stewart. 1986. Leaf area development in field-grown maize. Agron. J. 78:334-343.

Dwyer, L.M., D.W. Stewart, R.I. Hamilton, and L. Houwing. 1992. Ear position and vertical distribution of leaf area in corn. Agron. J. 84:430-438.

Foyer, C., R. Leegood, and D. Walker. 1982. What limits photosynthesis? Nature (London) 298:326.

Francis, C.A., J.N. Rutger, and A.F.E. Palmer. 1969. A rapid method for plant leaf area estimation of maize (Zea mays L.). Crop Sci. 9:537-539.

Gitelson, A.A., A. Viña, T.J. Arkebauer, D.C. Rundquist, G. Keydan, and B. Leavitt. 2003a. Remote estimation of leaf area index and green leaf biomass in maize canopies. Geophys. Res. Lett. 30:1248. doi:10.1029/2002GL016450.

Gitelson, A.A., U. Gritz, and M.N. Merzlyak. 2003b. Relationships between leaf chlorophyll content and spectral reflectance and algorithms for non-destructive chlorophyll assessment in higher plant leaves. J. Plant Physiol. 160:271-282.

Gitelson, A., A. Viña, S. B. Verma, D. C. Rundquist, T. J. Arkebauer, G. Keydan, B. Leavitt, V. Ciganda, G. G. Burba, and A. E. Suyker. 2006a. Relationship between gross primary production and chlorophyll content in crops: Implications for the synoptic monitoring of vegetation productivity. J. Geophys. Res., Vol. 111, D08S11. doi:10.1029/2005JD006017.

Gitelson, A.A., G.P. Keydan, and M.N. Merzlyak. 2006b. Three-band model for noninvasive estimation of chlorophyll, carotenoids, and anthocyanin contents in higher plant leaves. Geophys. Res. Lett. 33:L11402. doi:10.1029/2006GL026457.

Gitelson, A.A., A. Viña, J.G. Masek, S.B. Verma, and A.E. Suyker. 2008. Synoptic monitoring of gross primary productivity of maize using Landsat data. IEEE Geosci. Remote Sensing Lett. 5:133-137.

Keating, B.A., and B.M. Wafula. 1992. Modelling the fully expanded area of maize leaves. Field Crops Res. 29:163-176.

Kull, O. 2002. Acclimation of photosynthesis in canopies: Models and limitations. Oecologia 133:267-279.

Lieth, H., and R.H. Whittaker. 1975. Primary production of the biosphere. Springer-Verlag, New York.

Lizaso, J.I., W.D. Batchelor, and M.E. Westgate. 2003. A leaf area model to simulate cultivar-specific expansion and senescence of maize leaves. Field Crops Res. 80:1-17.

Long, S.P. 1991. Modification of the response of photosynthetic productivity to rising temperature by atmospheric $\mathrm{CO}_{2}$ concentrations. Has its importance been underestimated?- Opinion. Plant Cell Environ. 14:729-739.

Montgomery, E.G. 1911. Correlation studies in corn. 24th Ann. Rep., 113114. Nebraska Agric. Exp. Stn., Lincoln.

Ritchie, S.W., J.J. Hanway, and G.O. Benson. 1993. How a corn plant develops. Spec. Rep. 48. Iowa State Univ. of Science and Technology Coop. Ext. Serv., Ames.

SAS Institute. 2004. SAS/Stat user's guide. Version 9.1. Available at www. sas.com (verified 16 July 2008). SAS Inst., Cary, NC.

Ustin, S.L., M.O. Smith, S. Jacquemoud, M.M. Verstraete, and Y. Govaerts. 1998. GeoBotany: Vegetation mapping for earth sciences. p. 189-248. In A.N. Rencz (ed.) Manual of remote sensing: Remote sensing for the earth sciences. 3rd ed. Vol. 3. John Wiley \& Sons, New York.

Valentinuz, O.R., and M. Tollenaar. 2004. Vertical profile of leaf senescence during the grain-filling period in older and newer maize hybrids. Crop Sci. 44:827-834.

Valentinuz, O.R., and M. Tollenaar. 2006. Effect of genotype, nitrogen, plant density, and row spacing on the areaj-per-leaf profile in maize. Agron. J. 98:94-99.

Viña, A., and A.A. Gitelson. 2005. New developments in the remote estimation of the fraction of absorbed photosynthetically active radiation in crops. Geophys. Res. Lett. 32:L17403. doi:10.1029/2005GL023647.

Watson, D.J. 1947. Comparative physiological studies on the growth of field crops: I. Variation in net assimilation rate and leaf area between species and varieties, and within and between years. Ann. Bot. (London) 41:41-76.

Wolfe, D.W., D.W. Henderson, T.C. Hsiao, and A. Alvino. 1988. Interactive water and nitrogen effects on senescence of maize. II. Photosynthetic decline and longevity of individual leaves. Agron. J. 80:865-870.

Yang, J., and M. Alley. 2005. A mechanistic model for describing corn plant leaf area distribution. Agron. J. 97:41-48. 